CHAPTER 9

\title{
The conservation and management of Meteora (1960 to present): analysis
}

\subsection{Overview}

The recent history of Meteora may be divided, in terms of the conservation and management of the site, into three broad phases, on the basis of the changing relationship between monasticism, heritage protection and tourism operation over time.

\section{Phase A: the 1960s}

This is the period of few visitors in the site, before the establishment of an organised tourist system.

In this phase Meteora functioned primarily as a monastic site. The local community was involved in the ritual life of the site, comprising the congregation of the monasteries, which means that at that time visiting the site was incorporated within its monastic function. The monastic communities and the local community, with the support of the official Church, attempted to protect the fabric of the site, something that indicates that protection was also situated within the monastic function of the site.

\section{Phase B: the 1970s and the early 1980s}

This is the period of an increase in the number of visitors in the site and the development of state-sponsored organised tourism.

In this phase the visitors started being attracted to the site for reasons other than its monastic function. The government agencies supported the development of tourism for non-religious purposes, and the monastic communities were primarily concerned about the financial gains derived from tourism and did not actively encourage the visitors to participate in the ritual life of the site. The local community continued to be involved in the religious life of the monasteries as the congregation of the monasteries (which had become much greater than in phase A), but also started becoming increasingly involved in tourism. Also, at that time the State became increasingly concerned about the protection of the heritage significance of the site, linking protection to the development of tourism at the site rather than to its monastic function. 
Therefore, in this phase the site remained primarily a monastic one, used mainly by the monastic communities and their congregation. The heritage protection and the tourism exploitation of the site, however, started developing separately from its monastic function, with the acquiescence and even the encouragement of the monastic communities. The monastic function and the heritage protection of the site started to be increasingly linked to its tourism exploitation.

\section{Phase C: from the mid-1980s, especially the mid-1990s, to present}

This is the period of the development of mass tourism industry on the site. Mass tourism has had huge implications for the site and also the broader region. The monastic communities became even more actively concerned about tourism, and interested in the financial benefits derived from it. Elements of the local community became clearly interested in the tourism industry, ceasing to constitute the congregation of the monasteries. Also, at that time the State established the heritage significance of the site at an international level, by promoting the site for World Heritage inscription, and linked the inscription to the promotion of tourism at the area. The World Heritage inscription process was carried out without the involvement of the monastic communities.

Therefore, in this phase the site remained a monastic one, but the heritage protection and the tourism exploitation of the site were developed and established clearly separately from the monastic function, with the acquiescence and even the encouragement of the monastic communities. The tourism exploitation of the site was increasingly emphasised at the expense of the monastic function and the heritage protection of the site.

The operation of the site has become formalised today as follows. The monasteries are mainly occupied by the visitors from $c a 9$ in the morning to $c a 5$ in the afternoon (possibly with a small break). Outside these hours the monasteries are exclusively used by the monastic communities. In the Holy services on Sundays and on major feasts there is participation of the congregation, consisting mostly of members of the local community. Thus, the congregation has been incorporated within the life of the monastic communities, while the life of the monastic communities (including the congregation) seems to have adjusted to the presence of the visitors.

\section{Conclusion}

As this analysis shows, the most important factor that has affected the life of Meteora throughout its recent history is the growth of the tourism industry: it is on the basis of the increasing pressure from tourism that the recent history of Meteora was divided into three phases. Tourism did not emerge as a result of monastic activity, but was the result of broader, global changes supported by the Greek state; the monastic communities, however, willingly accepted and encouraged tourism, in accordance with their philanthropic-missionary approach to monasticism.

The monastic communities' response to tourism has been complex, and may be summarised in the following remarks. First, they claimed their aim was to put emphasis on their monastic life, and thus attempted to integrate tourism within their monastic life and use tourism as a means to promote the Orthodox faith to the visitors. The result has been exactly opposite: the monastic communities actually saw tourism as a means to achieve financial benefits, and did not attempt to incorporate it into their monastic life. As a consequence, the visitors were excluded from the worship of God. What happened was that monastic life was made to conform to the requirements of the growth of tourism, especially in phases B and C of the recent history of the site. Second, they attempted to combine the monastic function, the heritage protection and the tourism development of the site. However, the result was a clear separation between monastic function on the one hand and heritage protection and tourism operation on the other, especially in phases B and C. Third, they accepted and encouraged the growth of tourism at the site. The result 
was that this increasing emphasis on tourism developed clearly at the expense of the monastic function and the heritage protection of the site, especially in phases B and C. Therefore, as demonstrated in this section, the main problems in the operation and management of Meteora that developed over the course of the recent history of the site and have become formalised today are the following: the separation between monasticism, heritage protection and tourism operation; an increased emphasis on tourism; and the adjustment of monasticism to the pressure of tourism.

\subsection{Analysis}

In accordance with their philanthropic-missionary approach to monasticism, the Meteora monastic communities have accepted the growth of the tourism industry as a most effective means to promote the Orthodox faith on a large scale and at an international level. They have accepted their central position in the tourism industry, as the ones who control the access to the monasteries. They also recognise the significant benefits they derive from their position in the tourism industry: they keep all the entrance revenue for themselves, without sharing it with other groups involved in the operation of the site (for example, the Ministry of Culture), and also develop contacts with powerful people at local and state level (for example, politicians and major public officials) (see Ministry of Culture 1982b). Moreover, the monastic communities recognise the current requirements of the tourism industry, such as: mass tourism, 'package tourism', the tourism character of Meteora as a transitory destination based on a brief visit to the site, and the attempt to increase the visitor figures of the site. The monastic communities have adjusted their everyday monastic life to these requirements, in a way that does not hinder, but allows and even encourages the smooth operation of the tourism industry (Xydias and Totsikas and Braoudakis 1994, 4/3-5; see Meteora Monasteries 1994a, 37-41; Meteora Monasteries 1995, 23). There are numerous examples to illustrate this point. First, the opening hours of the monasteries are mostly adjusted to the needs of the visitors. Every day there are some monasteries open to visitors, while during the peak tourist season more monasteries remain open, and for longer periods of time. Second, the timing of the holy services is also adjusted to the requirements of tourism. The vespers, for example, is performed after the closure of the monasteries for the visitors. Third, the communal monastic activities [diakonimata] often serve the needs of the visitors. In larger monastic communities, such as the St Stephen monastic community for example, one of the key communal monastic activities is the running of the visitor shops and the arrangement of bureaucratic issues related to tourism. Fourth, there are even cases in which the monastic communities might perform activities outside their normal monastic schedule simply for the sake of the visitors. A characteristic example is the striking of the simantron [wooden gong inviting the monks to the holy services] in the Roussanou monastery at the request of the tour guides and the visitors. This kind of 'performance' sometimes places the Roussanou nuns in a difficult position, especially if the 'performance' is followed by the applause of the visitors (pers. comm. Maximi). Fifth, there are cases in which even the increase of the size of the monastic communities might relate to the increasing pressure of tourism and the satisfying of the needs of the visitors.

In accordance with their philanthropic-missionary approach to monasticism, the Meteora monastic communities have also accepted the increasing need for the maintenance and development of their monastery buildings, as a means to maintain their monasteries in a good condition. They clearly link the maintenance of their buildings to the tourism development of the site. They favour an increase in the visitor figures of their monasteries in the short term, without considering the potentially low carrying capacity of the site and the implications of tourism for the protection of the fabric and the landscape of the site. This was illustrated by their attitude towards the widening of the road network of the site. 
The government bodies seem to face an internal conflict. The Ministry of Culture, on the one hand, is concerned with the protection of the fabric and the landscape of the site, while the Ministry of Tourism and the Hellenic Tourism Organisation, on the other, are more concerned with the development of tourism at the area. The priority is clearly on the development of tourism, as illustrated in the widening of the road network and also in the failure of the Ministry of Culture to stop the completion of the Roussanou unauthorised buildings partly under the pressure from the Ministry of Tourism and the tourist agencies. Furthermore, this priority on the development of tourism is often linked to a focus on the short-term increase of the visitor figures of the site, without any respect to the low carrying capacity of the site, as illustrated in the widening of the road network.

The Ministry of Culture has no real control over the Meteora monastic communities with regards to heritage protection. As it was noted above, the Meteora monastic communities have their own perception of the maintenance and development of their monastery buildings (strictly within the continuation of their monastic presence in the site and the covering of their everyday monastic needs, as was illustrated in the case of the Roussanou access bridge), and do not need to depend on the Ministry of Culture officials, given their financial benefits and their contacts mostly through their role in the tourism industry. As a result, they have erected several unauthorised buildings in their monasteries, with considerable implications for the original fabric and space of their monasteries, even having the financial 'luxury' to afford to implement any projects and experiments of theirs on the space of their monasteries, as was illustrated in the case of the Roussanou new buildings. The number as well as the scale of the unauthorised buildings of the monastic communities, especially at the Roussanou monastery, seems to have raised questions about the removal of the site from the World Heritage List (pers. comm. Ministry of Culture) - a development that would unavoidably strike a blow to the international prestige of the Greek state in terms of its ability to protect sites of the significance and fame like Meteora (though this issue was not raised in the progress evaluation report: UNESCO 2006). The Meteora monastic communities cooperate with the Ministry of Culture mainly in the case that they attempt to maintain their independence or increase their power by stopping encroachments or threats from others, especially the local community, as illustrated in the re-definition of the buffer zone of the site.

The local community has a strong concern about the development of tourism at the area. However, there are certain severe obstacles (Kalyvas 2002, 81-84, 210-212 and 225-226; Alexiadis 2004; Anastasiou 2004; Charalambeas 2005, 232-252). First, the local community is caught within personal dislikes and local conflicts, and thus proves not able to come to a single view on tourism issues, as illustrated in its reactions towards the KENAKAP study. Second, the local community is caught within an attempt to increase the visitor figures of the site in the short term rather than trying to benefit from the current high visitor figures. Thus, it appears to be joining any project that tends to promise an increase in the tourist figures of the site, without any careful consideration of the implications and even the essence of the project. This was partly evident in the reaction of part of the local community towards the KENAKAP study. Third, the local community is clearly affected and influenced by the Meteora monastic communities. Consequently, the attempt of the local community to gain power in the tourism industry (at the expense of the monastic communities) failed, as evident in the rejection of the conclusions of the KENAKAP study and the subsequent passing of the law on the holiness of the site, and in the re-definition of the buffer zone of the site.

The local Bishopric is also influenced by the Meteora monastic communities. The monastic communities, given their power through the role in the tourism industry, have in practice a very high degree of independence from the local Bishopric in terms of operation and management. This position in turn seems to have led to an attempt by the local Bishopric to extend its officially 
strictly spiritual control into other areas of monastic activity, as reflected in the Bishopric's disagreement on the regular gathering of the Assembly.

Furthermore, the Meteora monastic communities' differing responses to tourism and differing ways to exercise the power derived from it, depending on their differing degree of commitment to the philanthropic-missionary approach to monasticism, are reflected in the management of the site as follows: Whenever there is an operational and management issue of the site that demands a single, unified view on the part of the monastic communities, it is mostly those communities more committed to the philanthropic-missionary approach that take the lead. Thus, it was those communities who led the way and managed to unify the other communities in all the major issues of the recent history of the site, such as: the campaign against the shooting of James Bond's film, the campaign against the KENAKAP study, and the passing of the law on the holiness of the site. Therefore, in practice, the responsibility for the management of the monastic site ends up being in the hands of a few monastic communities rather than being equally shared by all the monastic communities of the site. The gathering of responsibility in specific monastic communities has the following implications. First, the decisions taken reflect the views and principles of the few, and might not be fully shared by the other monastic communities. Second, the specific monastic communities unavoidably come to conflict with the other groups involved in the operation of the site, while the other monastic communities are deprived of this active role and have the 'privilege' of maintaining good relationship with the other groups. Third, the other groups of people demanding a role in the operation of the site attempt to form personal relationships with, and get attached to, the specific monastic communities.

Therefore, the Meteora monastic communities' attitude of acceptance towards tourism (in accordance with their philanthropic-missionary approach to monasticism) defines their relationship with the outside world, and particularly with the government bodies. The government bodies avoid conflicts and have to maintain good relationships with the monastic communities, and make compromises to ensure this. The monastic communities, in return, firmly avoid stopping access to their monasteries (though they theoretically have the right to do so being the owners of the monasteries), and comply with the requirements of the tourism industry. Thus, through tourism, the government bodies allow increased power to the monastic communities but at the same time keep them under control. It is even possible to argue that the gathering of controlling power, at a local level, by mainly the monastic communities, rather than the equal allocation of power to various groups of the site (with conflicting views), makes it easier for the government bodies to keep control over the operation of tourism at the region.

Each of the Meteora monastic communities' specific (active or passive) response to tourism (mostly in accordance with their specific degree of commitment to the philanthropic-missionary approach) further defines their relationship with the outside world and particularly with the government bodies. The government bodies, though often accusing specific monastic communities on gaining more benefits from the tourism industry and not concentrating on their monastic life, are actually in favour of active responses to tourism on the part of the monastic communities. The government bodies want a suppressed monastic life for the sake of the smooth running of the tourism industry, with the role of the monks being reduced to the maintaining of the monasteries (pers. comm. Ministry of Tourism). It is even possible to argue that the gathering of controlling power by specific monastic communities and Abbots, rather than the equal allocation of power between the monastic communities (with conflicting views), makes it even easier for the government bodies to keep control over the operation of tourism at the region. 